\title{
Langford v Secretary of State for Defence: taking a functional approach towards survivors' benefits?
}

\author{
KATHY GRIFFITHS
}

\author{
School of Law and Politics, Cardiff University
}

This is a commentary on Langford v Secretary of State for Defence, where the Upper Tribunal's decision was overruled by the Court of Appeal. The decision has implications for the payment of pensions and survivors' benefits in future cases, but, as will be argued here, the case is also important from a family law perspective.

Keywords: cohabitation; survivors' benefits; pensions; function-based recognition.

\section{Introduction}

L angford $v$ Secretary of State for Defence involves a claim to survivors' benefits for adult dependants granted under the Armed Forces and Reserve Forces (Compensation Scheme) Order 2011 (the Scheme). The Court of Appeal took a different approach from the Upper Tribunal and allowed the claim. The case has clear implications for the payment of survivors' benefits and will be of interest due to the discussion of principles deriving from the Supreme Court decision in Re Brewster. ${ }^{1}$ But it will be argued here that the decision is also important from a family law perspective, which has been largely overlooked so far, because the Court of Appeal decision points towards a need for comprehensive law reform in relation to the way the law treats unmarried cohabiting partners.

\section{Background}

The appellant, Mrs Langford, had been in a 15-year cohabiting relationship that was 'akin to marriage' 2 with her partner, Air Commodore Green, when he unexpectedly died in May 2011. Throughout, the appellant remained legally married to another man. She had been estranged from her husband for 17 years and received no financial support from him and had no expectation of receiving any in the future. Prior to Air Commodore Green's death, the couple had begun investigating the possibility of securing the appellant's divorce and had declared that they intended to marry. The appellant gave evidence that the couple shared the belief that, in the event of Air Commodore Green's death, regardless of whether they married, she would be entitled to survivors' benefits and a pension.

The procedural history of this case is complicated, and as such it is worth briefly outlining it here. The appellant began separate but parallel proceedings involving similar

1 [2017] UKSC 8.

2 Langford v Secretary of State for Defence [2019] EWCA Civ 1271, [4]. 
issues. As well as the claim to survivors' benefits under the Scheme, the appellant also claimed she was entitled to a pension under the Armed Forces Pensions Scheme. Both schemes contained similar rules as to when a surviving cohabiting partner would have entitlements upon their partner's death. 'Surviving adult dependants' would be entitled to benefits/pension provision in the same way as spouses and civil partners where they could prove four things. First, that they have cohabited with the deceased 'as partners in an exclusive and substantial relationship'; second, that the deceased did not leave a surviving spouse or civil partner; third, that they were 'not prevented from marrying' the deceased; and, fourth, that the survivor was financially dependent on the deceased or that the partners were financially interdependent. ${ }^{3}$ As the appellant remained married to her estranged husband, she could not have married her partner, ${ }^{4}$ and so her claim to a pension, as well as her initial claim to survivors' benefits, failed.

The High Court, ${ }^{5}$ in dismissing the appellant's claim to a pension, found that, while the appellant had been subject to differential treatment which fell within the ambit of Article 1 of Protocol 1 (A1P1) of the European Convention on Human Rights, the discrimination was justified because in the majority of cases, 'a person who is married, may be expected ... to have some claim on their spouse ... for financial support if needed'. ${ }^{6}$ Similarly, the Upper Tribunal ${ }^{7}$ in the proceedings about survivors' benefits held that the Secretary of State was entitled to treat 'married partners who would otherwise satisfy the definition of "surviving adult dependant" differently from unmarried partners' ${ }^{8}$ This was justifiable because a person who is dependent on another and is free to marry has no claim to financial support from a spouse, whereas a person who is dependent on another and is not free to marry, due to their already being married, is in a position to claim financial provision from their spouse. ${ }^{9}$

\section{The Court of Appeal decision and commentary}

The appellant appealed the Upper Tribunal's decision in relation to survivors' benefits. The appellant argued that the exclusionary rule in the Scheme, preventing the payment of survivors' benefits to a cohabiting partner who was prevented from marrying the deceased, discriminated against her unlawfully contrary to Article 14, read in conjunction with A1P1. She argued that her position was analogous to that of a surviving unmarried partner who does not have a continuing marriage to an estranged spouse because both would have been in a substantial and exclusive relationship, characterised by financial dependency, with the deceased. The exclusionary rule was not necessary to establish that the relationship between the appellant and the deceased was a 'substantial and exclusive' relationship, and the rule was inconsistent with the 'overarching objective' of the Scheme, which was to benefit unmarried couples. She further argued that it was disproportionate to withhold benefits from a dependent partner 'for want of compliance with a technicality'. ${ }^{10}$ The Secretary of State argued that the exclusionary rule was necessary and

3 Armed Forces and Reserve Forces (Compensation Scheme) Order 2011, Article 30; Armed Forces Pension Scheme Order 2005, Schedule 1, rules E.1 and E.2.

4 The Matrimonial Causes Act 1973, section 11(b), provides that a marriage will be void if one party is either already lawfully married or in a civil partnership. See similar provision in the Civil Partnership Act 2004, section 3(1)(b).

5 Langford v Secretary of State for Defence [2015] EWHC 875 (Ch).

6 Ibid [22] (Timothy Fancourt QC).

7 JL $v$ Secretary of State for Defence [2016] UKUT 0482 (AAC).

8 Ibid [39] (Mr E Mitchell).

9 Ibid.

10 [2019] EWCA Civ 1271, [13]-[14]. 
legitimate in order 'to achieve consistency of treatment between married and unmarried persons and to ensure the Scheme was affordable and administratively workable'. As such, it was argued that the difference of treatment was justifiable because it was not 'manifestly without reasonable foundation'. 11

Lord Justice McCombe, in the only reasoned judgment, allowed the appellant's appeal. It was explained that the aim of the Scheme was to ensure that partners of deceased Scheme members who had been in a substantial and exclusive relationship with the deceased were placed in the same position for the purposes of survivors' benefits regardless of whether they were married. ${ }^{12}$ The exclusionary rule was one way of determining whether a partner was entitled to benefit and was not indicative of any aim of the Scheme itself. ${ }^{13}$ In the present case, the exclusionary rule had the effect of discriminating between a person in the appellant's position, who was in a substantial and exclusive relationship with the deceased while remaining married to her estranged husband, and a person also in a substantial and exclusive relationship who was not married to the deceased or anyone else.

While the discriminatory treatment fell within the ambit of Article 14, read with $\mathrm{A} 1 \mathrm{P} 1,{ }^{14}$ in order to deny the appellant's claim, the discrimination needed to be justified and proportionate, which, following $\mathrm{Re}$ Brewster, ${ }^{15}$ required the court to determine whether the rule was 'manifestly without reasonable foundation'. This required the court to examine the reasons advanced for the difference of treatment 'and start from the basis that unless it is shown that it is without reasonable foundation then justification is established'. ${ }^{16}$ The Secretary of State put forward three legitimate aims in favour of the exclusionary rule: first that the Scheme intended to treat married and unmarried partners in the same way; second that the exclusionary rule attempted to prevent double recovery, in case the partner's spouse was also a member of the same/a similar public service scheme; and, third, to avoid increasing the cost of the scheme and creating administrative inconvenience. ${ }^{17}$ In line with Brewster, there was no evidence that the second and third aims were relevant to the introduction of the exclusionary rule, and as such they weighed less heavily in the assessment of reasonableness. ${ }^{18}$ In relation to the first aim, achieving the legitimate aim of parity of treatment between married and unmarried partners is achieved by requiring the unmarried partner to prove they shared a substantial, exclusive and financially dependent relationship with the deceased; there was no need to impose further restrictions based on marital status. ${ }^{19}$ In relation to the second and third aims, there was no evidence as to the likely numbers of people involved or evidence to suggest that allowing such claims would increase costs or administrative inconvenience. ${ }^{20}$ As such, it was held that none of the aims stated by the Secretary of State gave rise to a reasonable foundation.

It seems that, while the Upper Tribunal was concerned with a literal reading of the provisions and focused on the fact of the appellant's marriage to her estranged husband,

11 Ibid [15].

12 Ibid [35].

13 Ibid [36].

14 Ibid [38].

15 [2017] UKSC 8.

16 [2019] EWCA Civ 1271, [56]

17 Ibid [60].

18 Ibid [61].

19 Ibid [62]-[63].

20 Ibid [64]-[66]. 
the Court of Appeal took a more flexible, or functional, approach. As Jenni Millbank explains: '[f]unctional family claims rest on a performative aspect, that is, the parties are granted legal rights because of what they do in relation to one another, not because of the status of who they are or what manner of legal formality they have undertaken'.21 Arguably, Lord Justice McCombe has adopted a functional analysis in order to allow the appellant's claim to survivors' benefits. He explained that the legitimate aim of parity of treatment between married and unmarried partners 'is in reality achieved, not by imposing restrictions based on a partner's marital status, but by requiring the demonstration of a substantial, exclusive and financially dependent relationship in practice'. ${ }^{22}$ Considering the overall aim of the Scheme, instead of focusing on the technicality of the appellant's legal marriage to her estranged husband, allowed the court to focus on the fact that the relationship was a substantial and exclusive relationship characterised by financial interdependency, or to use Lord Justice McCombe's phrasing, a relationship 'akin to marriage'. As such, the technicality of the appellant's marriage could be overlooked by adopting a functional approach which focused on the nature of the relationship and the aim of the Scheme.

While this approach is to be welcomed because it ensures the appellant received survivors' benefits, Lord Justice McCombe explained in his concluding paragraph that, although the discrimination in the appellant's case cannot be justified and is not proportionate, this does not mean that other cases involving similar exclusionary rules would be decided in the same way. ${ }^{23}$ It seems to be a matter of evidence: if sufficient evidence could be raised to demonstrate that an exclusionary rule is justified and proportionate, then a surviving partner, such as the appellant, may not have a claim. These concluding comments are a cause of concern and point towards the need for general law reform in the area of cohabitation: a cohabiting partner in Mrs Langford's position could find themselves in a position of real financial need on their partners' death. Mrs Langford believed (as did her deceased partner) that she would be entitled to benefits upon her partners' death, and this corresponds with the findings of a recent study that found that 46 per cent of people in the UK continue to believe that cohabitants are treated in law as if they were married. ${ }^{24}$ In fact, the legal position of cohabiting couples is complicated. As Anne Barlow and others succinctly put it, 'sometimes the law treats cohabitants as married, sometimes ignores the relationship altogether and treats them as individuals, and in other instances treats them as a couple, but a couple which is inferior to their married counterparts'. ${ }^{25}$ Law reform is needed so that individuals like Mrs Langford in long-term cohabiting relationships are not having to fight their case in the courts in order to achieve benefits that would be provided to a spouse in the same position.

21 J Millbank, 'The limits of functional family: lesbian mother litigation in the era of the eternal biological family' (2008) 22(2) International Journal of Law, Policy and the Family 149, 150 (emphasis in original text).

22 [2019] EWCA Civ 1271, [63].

23 Ibid [68].

24 NatCen, 'Almost half of us mistakenly believe that common law marriage exists' (22 January 2019) <www.natcen.ac.uk/news-media/press-releases/2019/january/almost-half-of-us-mistakenly-believe-thatcommon-law-marriage-exists $>$.

25 Anne Barlow, Simon Duncan, Grace James and Alison Park, Cohabitation, Marriage and the Law: Social Change and Legal Reform in the 21st Century (Hart 2005) 6. 